\title{
Creación literaria
}

\author{
SANDRA JOHANA SILVA CAÑAVERAL ${ }^{1}$
}

\section{Vestidos orales}

\section{Oral Dresses}

Este texto -de corte anecdótico- trata acerca de mi primer encuentro con tres, de las cinco mujeres transgénero de El Parque La Libertad con quienes sucedió el acontecimiento estético-artístico que dio cuerpo a la obra de arte relacional Vestidos Orales.

\section{Carrera 9 con calle 14, esquina. Parque La Libertad de Pereira, Risaralda-Colombia.}

El recorrido inicia desde la calle catorce con carrera séptima en compañía de Abelardo (el periodista). Una vez cruzo el Parque La Libertad el dolor de cuello se incrusta en el cuerpo como si llevara un bulto a cuestas. Son las miradas de las personas las que me resultan inquietantes. Puedo sentir el peso de su acecho.

- ¡Vienen por nosotros Abelardo, nos van a robar, ellos saben que no pertenecemos a este lugar!-.

El periodista responde de manera contundente: ¡Cálmate!, en los muchos recorridos que he realizado por el parque nunca he sido víctima de un episodio delictivo. Además, tengo una conocida en el sector-.

Apuramos el paso hasta la carrera novena en búsqueda de Martha, la conocida de Abelardo, una mujer de aproximadamente sesenta años dedicada a la prostitución y quien el fin de semana pasado le había prometido al periodista ponernos en contacto con su líder, una travesti apodada «La Pulga».

No era difícil ubicar a Martha porque permanecía parada en la puerta de un prostíbulo aledaño al parque. Pese a nuestra cita, Martha no estaba. Así que decidimos lanzarnos a preguntar por ella. Al acercarnos a la puerta y saludar, ha salido de la oscuridad una mujer, que con voz grave, exhibiendo sus senos y lanzándonos una fumarada de marihuana a la cara contesta que Martha se ha ido para su casa.

- ¡Ay Jueputa qué susto!

Con mis voz entrecortada e intentando sobreponerme a la confusión, pues tal mujer parecía más bien un travesti, le pregunté por «La Pulga». El periodista intervino rápidamente diciendo: 
- Estamos buscando a «La Pulga», ¿saben dónde podemos encontrarla?

Ellas, las mujeres transgénero al interior del prostíbulo, más conocidas por la jerga popular como las travestis o las trans, que también parecían estar asustadas porque las sorprendimos fumando, contestaron de forma amable diciendo que habían visto a «La Pulga» tomar un bus, que nos acercáramos a la señora del carrito de dulces para que nos diera más información.

Al preguntarle a la señora por «La Pulga» nos contestó con tono recio que ella había salido para el médico, que la llamáramos a ver si volvía a la catorce. Con el número telefónico de «La Pulga» apuntado en mi libreta, pero con el miedo consumado en la boca, tuve que llamarla.

- Buenas tardes «Pulga». Mucho gusto, soy Sandra Silva, artista, me interesa hablar con usted sobre un proyecto de arte en el Parque La Libertad. ¿Nos podríamos ver?

En un tono, algo flemático, contestó que regresaba al parque a las cuatro de la tarde, que la buscara en la puerta de HB. Me despedí casi a viva voz con la intención de hacerle saber a las personas alrededor que nos conocíamos.

Cuatro en punto de la tarde, un malestar corporal que parecía no tener fin y ahora sin la compañía del periodista. Por un momento pensé en posponer la cita. Pero de inmediato concluí que no asistir sería el equivalente a perder la confianza de la comunidad. Caminé hasta el Parque La Libertad, esta vez decidida en que si las cosas no se concretaban en tal encuentro, sería la señal para abandonar la idea de intentar un proceso en ese lugar. Por teléfono «La Pulga» me mencionó un lugar de encuentro. Esa era la clave. Intuí que era un prostíbulo, aunque, no me fue familiar el nombre.

$\mathrm{Al}$ aproximarme a las puertas de las residencias del parque sentí cómo los pies se fueron poniendo más pesados, como si los zapatos fueran de hierro macizo; y el oído, en una fragilidad indescriptible, perdía agudeza sonora.

- ¡Buenas tardes, chicas! ¿Aquí se encuentra «La Pulga»?

Una trans de casi dos metros de altura vino a mi encuentro para indicarme con su dedo índice en qué puerta se hallaba. En seguida vociferó mirando para HB:

- ¡La pequeña, necesita a «La Puga!».

Se estaba refiriendo a mí como la pequeña. Llevaba treinta segundos en la puerta y ya tenía mi propia chapa. Con el corazón latiendo vertiginosamente caminé hacia HB. Al asomar la cabeza por el resquicio de la puerta, la voz impasible que me había atendido por teléfono se hizo cuerpo:

- ¡Quiubo!, dijo ella. 
- ¡Buenas tardes, ¿usted es La Pulga? Yo soy Sandra, la persona que la llamó por la mañana.

Ella asintió con la cabeza y luego dijo: bién.

- Si quiere que hablemos es mejor arriba. ¡Valeria, Diana! vengan ustedes tam-

Empezamos a subir por las escaleras y a sortear entre los peldaños unos pequeños recipientes con pegamento bóxer. Después de esquivar olores y rostros jamás vistos y jamás sentidos nos dirigimos a una habitación de cuatro metros por cuatro metros.

A puerta cerrada y en un silencio ensordecedor, Diana y Valeria me dieron la mano en señal de saludo.

- Mucho gusto, Diana, Valeria.

Entonces di inicio a la que sería la conversación más importante de todo este proceso creativo. Descargando las manos sobre la ventana para evadir el temblor comencé a contarles qué me traía al lugar. Pasada una hora, la náusea y el sudor habían desaparecido. De pronto, ya no tuve miedo, y ellas tampoco.

Vestidos Orales es una obra creada y activada por Leidy (La Pulga), Diana, Valeria, Yuri y Gia, cinco mujeres transgénero de El Parque La Libertad y, un equipo de estudiantes y profesorxs creadorxs. Enfocada en la visibilización de otras formas de existir y conocer, esta experiencia da cuenta, a través de un diálogo convertido en código de moda, del encuentro entre unos seres, ellas y nosotrxs, que han sido marginados de la construcción del mundo y del saber. Para materializar ese artefacto sensible, con el cual daríamos a conocer esa construcción individual y colectiva del género en Leidy, Diana, Valeria, Yuri y Gia, fue esencial valorar los repertorios de saber en cada grupo: ellas poseen el saber sobre el género y nosotrxs el saber sobre las imágenes.

Esta experiencia inició en agosto de 2014 y culminó en agosto de 2015 con una exposición en el Museo de Arte de Pereira, una exhibición de piezas publicitarias en espacio público, la creación de dos piezas audiovisuales que circulan en internet como Días de Afrodita y Vestidos Orales, el desfile y exhibición de los trajes en la Marcha por la Diversidad Sexual y de Género y, un conversatorio sobre género y creación también en el museo. 